\title{
Polymorphism of $\beta$-lactoglobulin ( $\beta$-LG)|SacII gene and its association to milk protein and milk production in Saanen goats
}

\author{
R. Ambarwati ${ }^{1,2}$, S. Sutopo ${ }^{1}$ and E. Kurnianto ${ }^{1}$,* \\ ${ }^{1}$ Faculty of Animal and Agricultural Sciences, Diponegoro University, Tembalang Campus, \\ Semarang 50275 - Indonesia \\ ${ }^{2}$ Permanent address: Agriculture, Fisheries, and Food Center of Semarang Regency, \\ Ungaran 50514 - Indonesia \\ *Corresponding E-mail: kurniantoedy17@gmail.com \\ Received September 11, 2019; Accepted October 25, 2019
}

\begin{abstract}
ABSTRAK
Penelitian ini bertujuan untuk menganalisis dan mengidentifikasi genotip $\beta$-LG dan mengkaji asosiasi antara genotip $\beta$-LG dengan kadar protein dan produksi susu kambing Saanen. Materi penelitian yang digunakan yaitu DNA yang berasal dari 22 ekor kambing Saanen beserta rekording kadar protein susu dan produksi susu pada umur 2,5; 3,0;3,5 dan 4,0 tahun. DNA dianalisis menggunakan metode PCR-RFLP dengan enzim restriksi SacII untuk mengidentifikasi genotype gen B-LG yang terbentuk dan masing-masing sampel yang mewakili tiap genotip disekuensing. Data sekuensing gen $\beta$-LG dianalisis menggunakan Clustal W yang terdapat dalam software MEGA7.0, sedangkan asosiasi antara genotype gen $\beta$-LG dengan kadar protein susu serta produksi susu dianalisis dengan menggunakan metode General Linear Model (GLM) yang terdapat dalam software SAS 9.0. Hasil penelitian menunjukkan adanya dua alel (A dan G) yang membentuk dua genotip homozigot (AA dan GG) dan satu genotip heterozigot $(\mathrm{AG})$ dan tidak ditemukan adanya perbedaan antar genotype gen $\beta$-LG terhadap kadar protein dan produksi susu. Kesimpulan penelitian ini yaitu genotip gen $\beta$-LG tidak berasosiasi dengan kadar protein dan produksi susu kambing Saanen.
\end{abstract}

Kata kunci: genotip $\beta$-LG; kadar protein susu; kambing Saanen

\begin{abstract}
The objectives of this study were to analyze and identify the $\beta$-LG genotype and examine its association with milk protein and milk production of Saanen goats. Materials used in this study were DNA that originated from 22 Saanen does and its milk protein and milk production recording that was taken at 2,5;3,0;3,5 and 4,0 years old of Saanen does. DNA was analyzed using PCR-RFLP method with SacII restriction enzyme to identify genotype of B-LG gene and then were sequenced for each genotype. Sequencing data was analyzed using Clustal W in MEGA7.0, while association of B-LG gene genotype with milk protein and milk production was analyzed using General Linear Model (GLM) in SAS 9.0. The results showed that two alleles (A and G), forming two homozygous genotypes (AA and GG) and one heterozygous genotype (AG) were found, but there were no significant different within genotype on milk protein and milk production. In conclusion, there was no association between $\beta$-LG genotype and milk protein and milk production of Saanen goats.
\end{abstract}

Keywords: $\beta$-LG gene; milk protein percentage; saanen goat 


\section{INTRODUCTION}

It is known that milk contain 3-5\% of protein ( $80 \%$ casein and $20 \%$ whey) as was stated by Patel et al. (2007). Casein consist of $\alpha$-s $1, \alpha$-s $2, \beta$, and kappa-casein, while whey consist of $\beta$ lactoglobulin and $\alpha$-lactalbumin (El-Rafey et al., 2008). Sugiharto et al. (2015) mentioned that whey consist of $50 \% \beta$-lactoglobulin, $20 \% \alpha-$ lactalbumin, $10 \%$ bovine serum albumin (BSA) and $10 \%$ immunoglobulin (Ig).

$\beta$-lactoglobulin $(\beta-L G)$ is a non-casein whey protein that is dominant in mammalian milk, such as cattle, goats, and sheep (Kumar et al., 2006; ElHanafy et al., 2015; Kusza et al., 2015). According to Kontopidis et al. (2004), $\beta$-LG is the first protein found in polymorphism. It consist of 162 amino acids and has a molecular weight as much as $18 \mathrm{kDa}$ per monomer. Hambling et al. (1992) stated that $\beta$-LG genes of cow and goat are located on chromosome 11 that consisted of 7 exon, 6 intron and $8.088 \mathrm{bp}$, while those of the sheep is located on chromosome 3. Genotipycally, the $\beta$-LG gene is a candidate gene for milk composition, especially for milk protein percentage (Gharedaghi et al., 2016). Jain et al. (2012) stated that the $\beta$-LG gene polymorphism determines the quality and quantity of milk.

The $\beta$-LG gene polymorphism and its effect on milk production in goat have been studied by Kumar et al. (2006), El-Hanafy et al. (2015), ElHanafy et al. (2010), Isik et al. (2017) and Kahilo et al. (2014). In general, $\beta$-LG gene is influenced by the genotypes of goats. According to ElHanafy et al. (2010), the $\beta$-LG gene in the AA genotype Damascus goat produced higher milk yield than Barki goats (AA genotype) and their crossbred. Kumar et al. (2006) also reported that $\beta$-LG gene in AA genotype produced higher milk yield than those of $A B$ genotypes in Indian local goats. In local Saudy goat, El-Hanafy et al. (2015) found that $\beta-\mathrm{LG}$ gene in AA genotype is associated with higher milk yield than $\mathrm{AB}$ and $\mathrm{BB}$ genotypes. Isik et al. (2017) further reported that $\beta$-LG gene in S1S1 genotype produced higher milk production, so that $\beta$-LG gene can be used as molecular marker for milk production.

In addition to milk yield, the association of the $\beta$-LG gene with the milk composition, especially milk protein, has been reported in Iran goats by Gharedaghi et al. (2016), in sheep by Mroczkowski et al. (2004), Dario et al. (2005) and El-Shazy et al. (2012), and in cattle by Zaglool et al. (2016). Previous studies showed that the $\beta$-LG gene had a significant effect on the milk protein percentage in goats (Gharedaghi et al., 2016) and sheep (El-Shazly et al., 2012). To date, the relationship between $\beta-\mathrm{LG}$ and genotype in term of milk protein remains unclear. In term of genotype, Mroczkoswki et al. (2004) and Dario et al. (2005) showed that there was a significant relationship among $\beta$-LG, BB genotype and milk protein percentage in sheep. In cattle, $\beta$-LG in AA genotype had higher protein percentage as reported by Zaglool et al. (2016). In Indonesia, Saanen goats are known as good milk producers, and thereby their population are growing. Yet, there is no data regarding the relationship between $\beta$-LG and milk protein percentage in Saanen goats. Therefore, the objective of this study was to evaluate the association between $\beta-L G$ and genotype in term of milk protein percentage in Saanen goats.

\section{MATERIALS AND METHODS}

\section{Materials}

This study was conducted from in Baturraden Animal Breeding and Forage Center, Center Java. Milk protein and milk production record were obtained from individual Saanen doe at $2.5 ; 3.0 ; 3.5$ and 4.0 years old during the first until the fourth lactation. Molecular analysis was performed at the Laboratory of Animal Breeding and Genetics, Faculty of Animal Husbandry, Universitas Gadjah Mada (UGM), Yogyakarta, while the $\beta$-LG gene sequencing was performed at the Laboratory of Integrated Research and Testing, UGM. Data analysis was performed at the Faculty of Animal and Agricultural Sciences, Diponegoro University, Semarang.

\section{Methods}

The methods of this study consisted of sample collection, DNA isolation, gene amplification, PCR-RFLP, sequencing, and data analysis.

\section{Data and Blood Samples Collection}

The study was performed by observational methods. The initial stage of the research was tracking the secondary data of periodic record of milk protein percentage and milk production from December 2015 to August 2018. The samples were selected by purposive sampling method. Twenty-two imported Saanen goats from Australia maintained under the same management at Baturraden Animal Breeding and Forage Center 
were used. Two $\mathrm{mL}$ blood sample was taken through the jugular vein. The blood was taken using a sterile venoject and was accommodated in a vacutainer tube containing anticoagulants. Samples were inserted into cooler box, and were stored at $-20^{\circ} \mathrm{C}$.

\section{DNA Isolation and Gene Amplification}

Genomic DNA was extracted using DNA extraction kit (gSYNCTM) with Sambrook et al. (2001) method, then it was electrophorese using $1.5 \%$ agarose gel stained with Ethidium Bromide to test the quality of DNA extracted. The DNA stocks were stored at $-20{ }^{\circ} \mathrm{C}$. Amplification of the $\beta$-LG gene of exon 7 was performed using the polymerase chain reaction (PCR) technique.

The PCR reaction was performed with a total volume of $25 \mu \mathrm{L}$ of the solution mixture consisting of $2 \mu \mathrm{L}$ genomic DNA, $9.5 \mu \mathrm{L}$ DDW, $12.5 \mu \mathrm{L}$ PCR Kit, $0.5 \mu \mathrm{L}$ Forward Primer (5'CGGGAGCCTTGGCCCCTCTG-3'), and $0.5 \mu \mathrm{L}$ Reverse Primer (3'-CCTTTGTCGAGTTTG GGTGT-5'). The reaction condition in the PCR machine was designed with a temperature of $95^{\circ} \mathrm{C}$ for 5 minutes (predenaturation), then 35 reaction cycles consisting of $95^{\circ} \mathrm{C}$ for 30 seconds (denaturation), $65^{\circ} \mathrm{C}$ for 1 minute (annealing), $72^{\circ} \mathrm{C}$ for 90 seconds (extension), and $72^{\circ} \mathrm{C}$ for 5 minutes (final extension). The PCR product was then electrophoresed using $1.5 \%$ agarose gel.

\section{PCR-RFLP and Sequencing}

The PCR products were cut using SacII enzyme. The RFLP (Restriction Fragment Length Polymerase) reaction was performed with a total volume of $15 \mu \mathrm{L}$ consisting of $4 \mu \mathrm{L}$ PCR products, $9 \mu \mathrm{L}$ DDW, $1.5 \mu \mathrm{L}$ Buffer B, and $0.5 \mu \mathrm{L}$ SacII enzymes. The solutions were incubated at $37^{\circ} \mathrm{C}$ for 16 hours (overnight). The band pattern of PCR-RFLP was visualize using $1.5 \%$ agarose gel electrophoresis. Sequencings was conducted to ensure the point of mutation. Sequencing results were analyzed using MEGA software version 7 .

\section{Data Analysis}

\section{Allele and Gene frequency}

Allele frequency was calculated using the following formula of Warwick et al. (1995):

$$
\mathrm{FAi}=\frac{\sum \text { Allele } \mathrm{Ai}}{\sum \text { Allele } \mathrm{Ai}+\sum \text { Allele } \mathrm{Bi}+\ldots . .+\sum \text { Allele Ni }}
$$

$\mathrm{F}_{\mathrm{Ai}}=$ Allele frequency of allele $\mathrm{A}$ on locus $\mathrm{i}$

Genetic diversity within Saanen goat population was quantified by measuring average heterozygosity $(\mathrm{H}$ bar) that it as estimated from expected propotion of locus heterozygosity using formula of Nei (1987), as follows:

$$
\bar{H}=\frac{1-\sum q_{i}^{2}}{r}
$$

Where:

$\mathrm{q}_{\mathrm{i}}=$ allele frequency in $\mathrm{i}^{\text {th }}$ protein locus

$\mathrm{m}=$ number of allele

$\mathrm{r}=$ number of locus

Expected genotype frequency value was calculated based on Hardy-Weinberg Equilibrium (HWE) theory (Falconer and Mackay 1996) by following equation:

$$
p^{2}+2 p q+q^{2}=1
$$

Where:

$\mathrm{p}=$ allele frequency of first allele

$\mathrm{q}=$ allele frequency of second allele

HWE was calculated using Chi-square test that was applied to compare the heterozygosity value between expected and observed genotype value (Hartl and Clark 1997):

$$
x^{2}=\sum_{i=1}^{k} \frac{\left(O_{i}-E_{i}\right)^{2}}{E_{i}}
$$

Where:

$x^{2}=$ Chi square value

$O_{i}=$ observed genotype frequency value

$E_{i}=$ expected genotype frequency value

$x^{2}$ table using 5\% significance level for HWE test

\section{Genotypic Association with Milk Protein}

The analysis of $\beta$-LG genotype with milk protein and milk production was performed using the General Linear Model (GLM) on Statistical Analysis System (SAS) software version 9.0 (2004). The model used was:

$$
\begin{aligned}
\mathrm{Y}_{\mathrm{ij}}= & \mu+\tau_{\mathrm{i}}+\varepsilon_{\mathrm{ij}} \\
\mathrm{Y}_{\mathrm{ij}}= & \text { observation value (milk protein or } \\
& \text { milk production) of } \mathrm{j}^{\text {th }} \text { animal whose } \\
& \text { had } \mathrm{i}^{\text {th }} \text { genotype } \\
\mu \quad= & \text { over all mean population } \\
\tau_{\mathrm{i}}= & \text { effect of } \mathrm{i}^{\text {th }} \text { genotype }(\mathrm{i}=1(\mathrm{AA}), 2 \\
& (\mathrm{AG}), 3(\mathrm{GG})) \\
\varepsilon_{\mathrm{ij}}= & \text { the random residual for } \mathrm{Y}_{\mathrm{ij}}
\end{aligned}
$$

Where: 


\section{RESULTS AND DISCUSSION}

Sequences of $\beta$-LG target genes in goats $(C$. hircus) based on GenBank (2018) with access number Z33881.1 were presented in Figure 1. Amplification of $\beta$-LG gene fragments in Saanen goats obtained $427 \mathrm{bp}$ products, and it was indicated by the $1.5 \%$ agarose gel electrophoresis (Figure 2). PCR-RFLP analysis showed that SacII restriction enzyme was able to cut $\beta$-LG gene with the cutting position $\left(5^{\prime} \ldots\right.$. CCG $\mid \mathrm{GG} \ldots 3^{\prime} / 3^{\prime} \ldots$ GG|CGCC ... 5 $5^{\prime}$ ) on the 6752 nucleotide sequence (Figure 1).

Two alleles (A and G) forming two homozygous genotypes, namely AA genotype (427 bp) and GG genotype (347 bp and $80 \mathrm{bp}$ ); and one heterozygous genotype, namely AG genotype ( $427 \mathrm{bp}, 347 \mathrm{bp}$, and $80 \mathrm{bp}$ ) were found (Figure 3 ). The results of the $\beta-\mathrm{LG}$ gene sequences in chromatograms form are presented in Figure 4. The genotype and alleles frequency of the $\beta$-LG gene in Saanen goat were presented in Table 1. The frequencies of AA, AG, and GG genotypes were $0.32,0.45,0.23$, respectively, while the frequencies of A and G alleles were 0.55 and 0.45 , respectively. Genotypes distribution of $\beta$-LG gene in this study were not statistically difference $(\mathrm{P}>0.05)$ from HWE and frequency of heterozygosity was $49.6 \%$. Based on Chi square test, population in this study was in HWE condition with high heterozygosity which was describing the diversity of $\beta-\mathrm{LG}$ gene. The AG genotype this study showed the highest frequency, followed by $\mathrm{AA}$ and GG. The frequency of dominant $\mathrm{A}$ allele $(0.55)$ is higher than $\mathrm{G}$ allele (0.45). The results of genotypic association with milk protein and milk production of Saanen goats are presented in Table 2 and Table 3. The result showed that there were no significant difference among $\beta$-LG genotype (AA, AG and GG) in this study on milk protein and milk production.

Amplification of $\beta$-LG gene fragments in Saanen goats in this study was in accordance with the previous studies using the same primer which showed $427 \mathrm{bp}$ in local Saudi goats and Saanen goats in Turkey (El-Hanafy et al., 2015; Isik et al., 2017). Previous research by El Hanafy et al. (2010) found three genotypes, namely AA (426

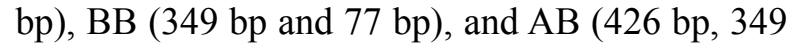
$\mathrm{bp}$, and 77bp) with two alleles (A, B) in Barki and Damascus goats in Egypt. Research on local Saudi Arabian goats by El Hanafy et al. (2015) revealed two alleles (A, B) and three genotypes: AA (427bp), BB (349 bp and 78 bp) and AB (427 bp, 349 bp and 78 bp). Isik et al. (2017) found two alleles (S1, S2) and three genotypes: S1S1 (347 bp, 80 bp), S1S2 (427 bp, 347 bp, 80 bp), and S2S2 (427 bp). There are two alleles, A and G in this study (which is the same as A and B or S1 and $\mathrm{S} 2$ in the previous study mentioned above), and three genotypes AA, AG, and GG. Two different alleles (S1 and S2) with three restriction patterns (S1S1, S1S2, S2S2) were seen following the gene amplification using SacII digest. In a number of work, the genotypes of S1S1, S1S2 and $\mathrm{S} 2 \mathrm{~S} 2$ have been regarded as $\mathrm{BB}, \mathrm{AB}, \mathrm{AA}$ (Yuksel et al., 2014). PCR-RFLP using the SacII enzyme was able to recognize the polymorphisms produced by single nucleotide substitution (Pena et al., 2000).

The results of the $\beta$-LG gene sequences in Saanen goats in the form of data chromatograms are presented in Figure 4. The difference in the pattern of cutting bands with restriction enzymes occurred due to mutations in DNA sequences (Zurriyati et al., 2011). The chromatogram data showed that there was mutations (SNP) in 6752 position of sequence or on the $79^{\text {th }}$ position from the forward primer. In the AA genotype, there were mutations from $\mathrm{G}$ to A nucleotide, therefore the restriction enzyme cannot recognize the cutting site, and the nucleotide sequence changes to $\left(5^{\prime} \ldots\right.$. CCACGG ... 3' / 3' ... GGCACC ... 5') so that a 427 bp band was formed (Figure 3) with one curve $\mathrm{A}$ in green (Figure 4). In the GG genotype, one allele did not change $(\mathrm{G} \rightarrow \mathrm{G})$, so the restriction enzyme was able to recognize the cutting site into two bands ( $347 \mathrm{bp}$ and $80 \mathrm{bp}$ ). However, in the paired strain, the restriction enzyme cannot recognize the SNP $(\mathrm{G} \rightarrow \mathrm{A})$ site, therefore it formed 3 bands: $427 \mathrm{bp}, 347 \mathrm{bp}$ and 80 bp (Figure 3) with $2 \mathrm{~A}+\mathrm{G}$ (Figure 4). In the GG genotype, there was no mutation so the SacII enzyme was able to recognize the cutting site $\left(5^{\prime} \ldots\right.$. CCGC $\mid$ GG ... 3' / 3' ... GG $\mid$ CGCC ... 5') and then the product cut into 2 bands along 347 bp and $80 \mathrm{bp}$. The nucleotide changed from $\mathrm{G}$ to A causing $\mathrm{CCG} \rightarrow \mathrm{CCA}$ codon (Prolin $\rightarrow$ Prolin). This mutation did not change the amino acid form so it can be categorized as silent mutation. Mutations in DNA caused the nitrogen base (DNA sequence) alteration. Mutations cause changes in amino acids that affect the genotype of the observed genes or do not change the composition of amino acids or known as silence mutation (Zurriyati et al., 2011).

El Hanafy et al. (2010) obtained three genotypes, namely $\mathrm{AA}, \mathrm{AB}, \mathrm{BB}$ with a genotypic 


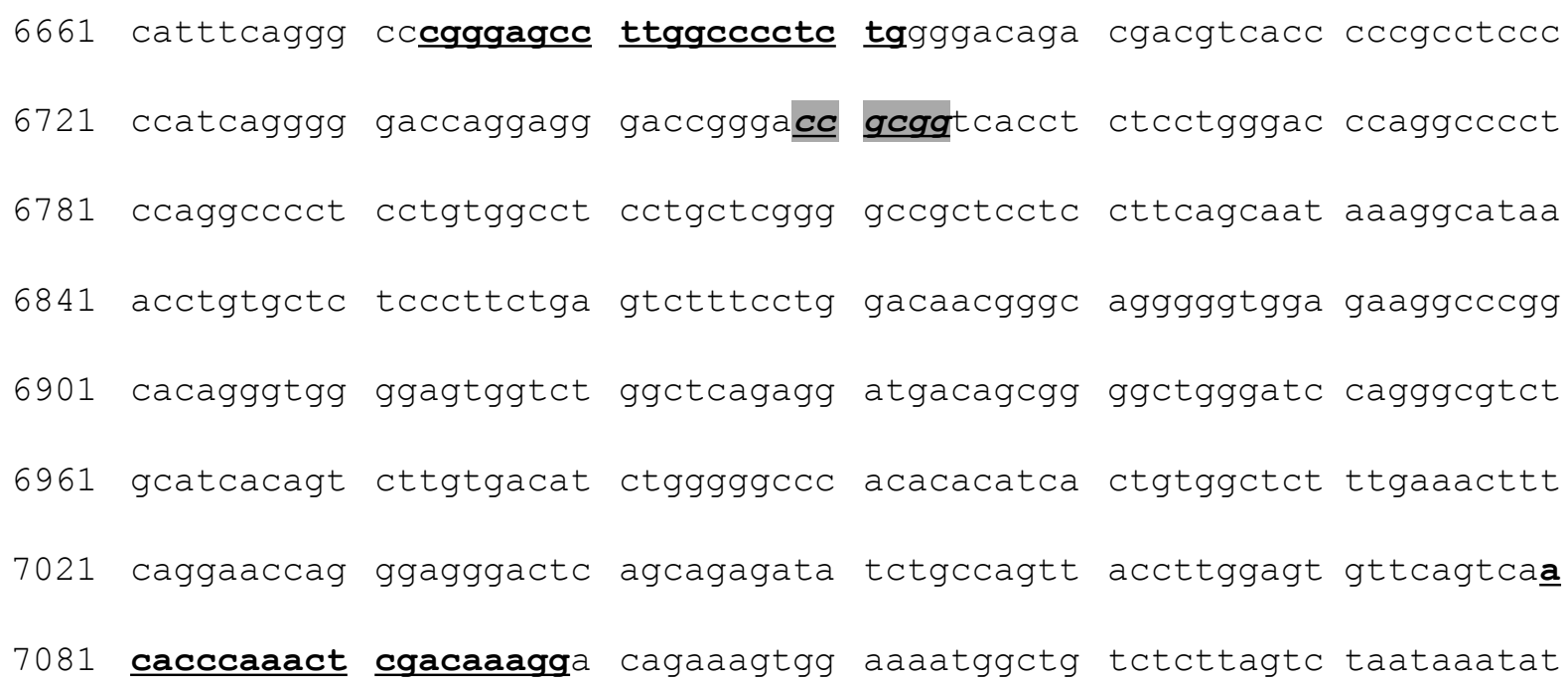

Figure 1. The target of the amplified gene. Sequences that are underlined and in bold are Primer-F and Primer-R; sequences that are bold, italicized, black colored and underlined are the restriction site (Source: sequence of $\beta$-LG goat genes (C. hircus) GenBank access numbers: Z33881.1)

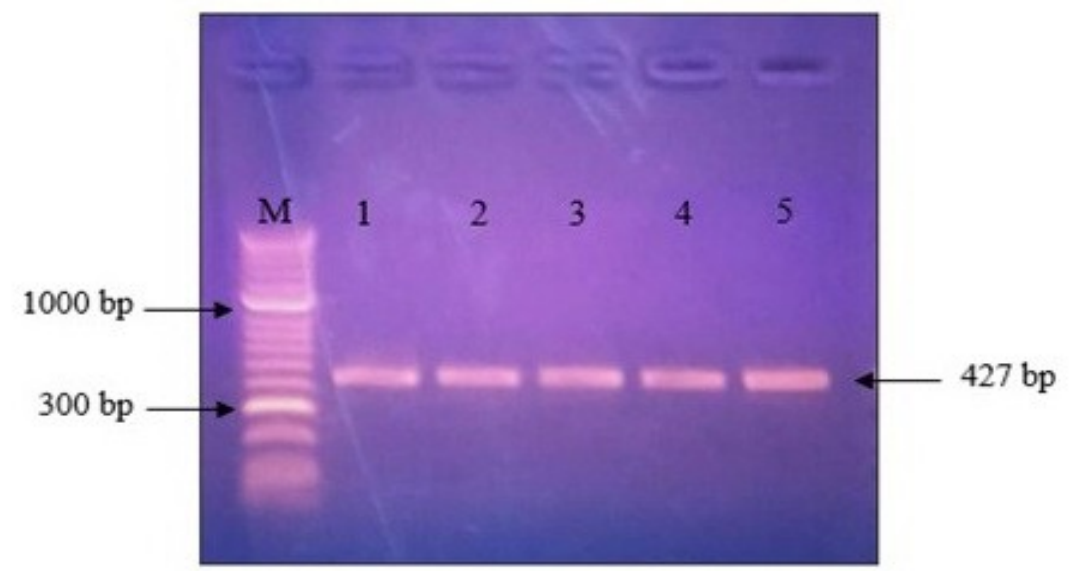

Figure 2. PCR Electrophoresis Results of the $\beta$-LG Gene Fragment ( $\mathrm{M}=$ DNA Marker)

frequency of $0.1,0.8,0.1 ; 0.85,0.1,0.05 ; 0.41$, $0.51,0.08$. In Barki, Damascus goats and crosses in Egypt, respectively, have the allele frequencies $(\mathrm{A}, \mathrm{B})$ of $0.50,0.50 ; 0.9,0.1 ; 0.66$, and 0.33 . The local goats in Saudi Arabia obtained three genotypes, $\mathrm{AA}, \mathrm{AB}$, and $\mathrm{BB}$ with a frequency of $0.08,0.4,0.52 ; 0.23,0.41,0.36 ; 0.09,0.34,0.57$ and two alleles, A and B with a frequency of 0.28 , $0.72 ; 0.43,0.57 ; 0.26$, and 0.74 , respectively (Mroczkowski et al., 2004). Isik et al. (2017) obtained allele frequencies of S1 and S2 as much as 0.59 and 0.41 , respectively and genotype frequency of S1S1, S1S2, S2S2 as much as 0.38 ,
0.43 , and 0.19, respectively, in Saanen goats in Turkey. Conversely likewise, Lekerpes et al. (2014) have recognized the S1 as predominant allele (frequency $0.76-0.86$ ) in two native goat in Kenya. The S2 allele frequency $(0.81)$ was seen to be high in Hair goat in Turkey (Yuksel et al., 2014). Based on those studies, it can be seen that $\mathrm{AG}$ or $\mathrm{AB}$ or S1S2 genotypes have the highest frequency compared to other genotypes. Previous research on Altamurana sheep in Italy by Dario et al. (2005) showed that $\mathrm{AB}$ genotype frequency was higher than other genotypes and the frequency of A allele was higher than B allele. 


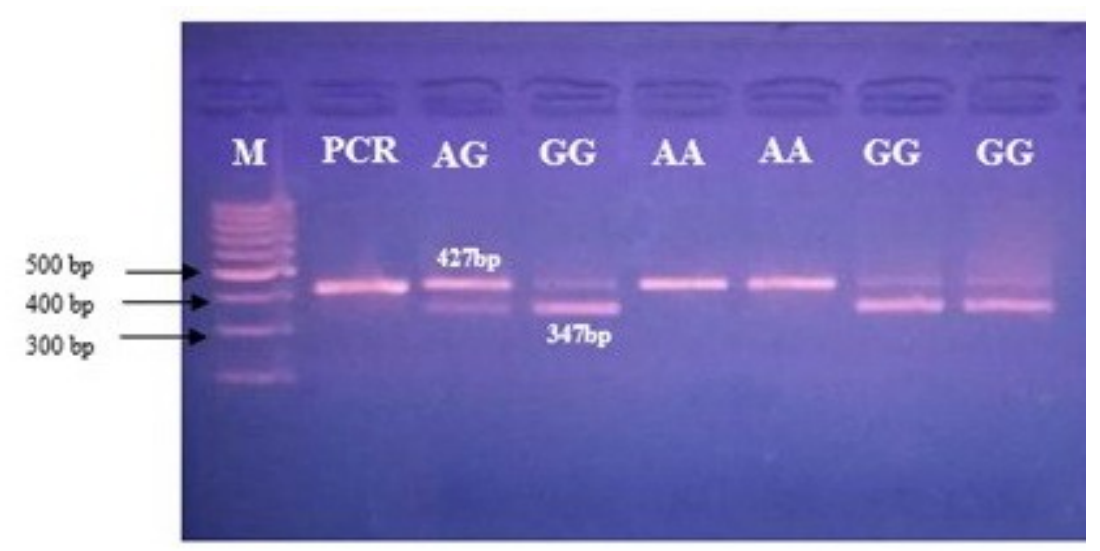

Figure 3. Restriction Results of the $\beta$-LG PCR Product by SacII Enzyme

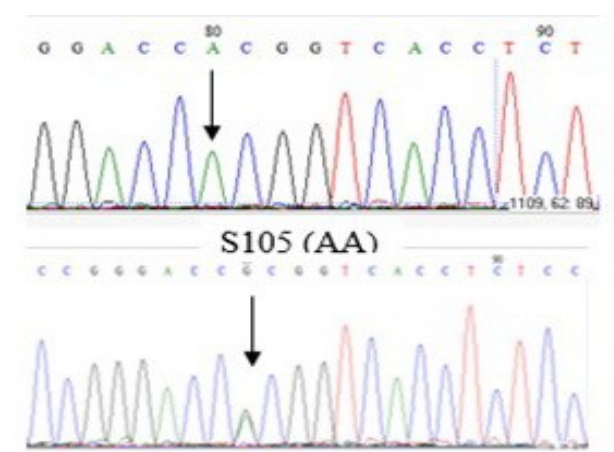

S042 (AG)

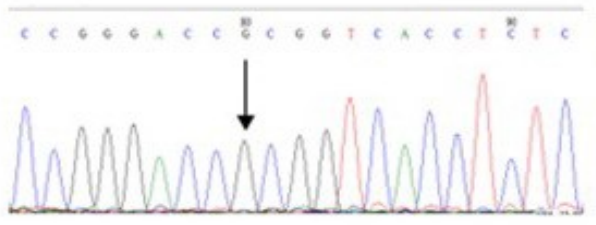

$\mathrm{S} 182(\mathrm{GG})$

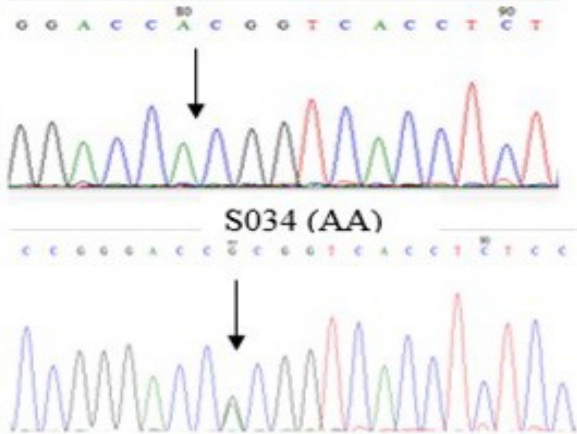

$\mathrm{S} 194(\mathrm{AG})$

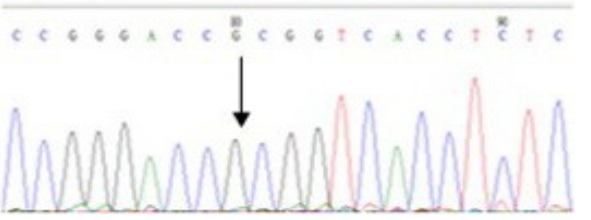

S119 (GG)

Figure 4. Chromatograms of AA, AG, and GG genotypes

This result was confirmed by studies on several sheep in Poland, resulting in two alleles (A, B) with dominant $\mathrm{A}$ allele frequency and three genotypes (AA, AB, $\mathrm{BB}$ ) with $\mathrm{AB}$ genotype frequencies higher than other genotypes (Kawecka et al., 2011). A and B alleles are common genes, A allele is associated with higher whey protein content and lower casein content (Ng-Kwai-Hang et al., 1998). Further explained by Yang et al. (2012) and Zaglool et al. (2016), the $\beta$-LG gene is very polymorphic in ruminants, $\mathrm{A}$ and $\mathrm{B}$ alleles appear most frequently and associate with milk yield and milk protein percentage. Studies on the attribution of the polymorphism to milk production exhibited the various result in terms of the impact of allele (Vacca et al., 2014).

This research showed that the older the animal and the level of lactation are, the higher the milk protein percentage is. According to Culotta and Schmidt (1988), the fat and milk protein percentage have an inverse association with milk yield. At the beginning of lactation, fat and milk protein are high, then both decrease rapidly and reach a minimum at 2-3 months of lactation period, and then increase again until the end of lactation period. The increasing fat and milk protein started from $6^{\text {th }}$ month of lactation. The percentages of milk protein and fat are at its 
Table 1. Genotype and Allele Frequency of $\beta$-LG Gene in Saanen Goats $(n=22)$

\begin{tabular}{|c|c|c|c|c|c|c|c|}
\hline \multirow{2}{*}{ Variable Measured } & \multicolumn{3}{|c|}{ Genotype } & \multicolumn{2}{|c|}{ Allele } & \multirow{2}{*}{$\mathrm{H}$} & \multirow{2}{*}{$\chi^{2}$} \\
\hline & GG & $\mathrm{AG}$ & $\mathrm{AA}$ & G & A & & \\
\hline Frequencies & 0.23 & 0.45 & 0.32 & & & & \\
\hline Observation & 5.00 & 10.00 & 5.00 & 0.45 & 0.55 & 0.496 & $0.153^{\mathrm{ns}}$ \\
\hline Expectation & 4.55 & 10.91 & 6.55 & & & & \\
\hline
\end{tabular}

Table 2. Average of Milk Protein (\%) in Different Age

\begin{tabular}{clll}
\hline \multirow{2}{*}{ Age (Years) } & \multicolumn{3}{c}{ Genotype } \\
\cline { 2 - 4 } & AA & AG & GG \\
\hline 2.5 & 2.71 & 2.68 & 2.75 \\
3.0 & 2.73 & 2.73 & 2.68 \\
3.5 & 2.76 & 2.79 & 2.78 \\
4.0 & 2.89 & 2.96 & 2.96 \\
\hline
\end{tabular}

Table 3. Average of Milk Production

\begin{tabular}{cccc}
\hline \multirow{2}{*}{ Lactation } & AA & Genotype & GG \\
\cline { 2 - 4 } & $509.12 \pm 49.90$ & $477.84 \pm 136.71$ & $539.81 \pm 78.73$ \\
1 & $626.87 \pm 68.49$ & $698.57 \pm 64.06$ & $673.70 \pm 73.91$ \\
3 & $553.81 \pm 83.27$ & $587.10 \pm 48.84$ & $565.45 \pm 35.42$ \\
4 & $446.08 \pm 45.18$ & $419.40 \pm 127.71$ & $468.74 \pm 12.92$ \\
\hline
\end{tabular}

lowest point when milk yield is at the peak of lactation and increases towards the end of lactation period. Total milk yield generally increases in the first month after parity and decreases gradually, while fat and protein content increases towards the end of lactation (Ensminger et al., 2006). Milk protein percentage is influenced by many factors, those are breed, genetics, age, lactation level, feed given, milking time and climatic conditions (Zurriyati et al., 2011).

The $\beta$-LG gene polymorphism can be used as a molecular marker for milk yield and milk composition traits (Selvaggi et al., 2015). The $\beta$ LG genotype in this study was not significant differences on milk protein percentage in Saanen goat. These results are consistent with the results in Holstein (Singh et al., 2014; Mir et al., 2014), Girolamo and Czech Fleckveck (Mir et al., 2014), Sahiwal (Mir et al., 2014; Kishore et al., 2014) and Mexican Jersey cattle (Batista et al., 2015), Bergschaf sheep (Kawecka et al., 2011), and Massese sheep (Mele et al., 2007).

In contrast, Gharedaghi et al. (2016) reported that the $\beta$-LG gene in Mahabadi goats in Iran had a significant effect on the milk protein percentage, 
but did not significantly influence milk yield and milk fat percentage. According to El-Shazy et al. (2012), $\beta$-LG genotypes in several types of sheep in Saudi Arabia did not have a significant effect on milk production but affect milk protein percentage. Some studies suggested that the AA genotype affect milk protein percentage, such as in the research of Coral et al. (2010) in sheep and research by Piatkoswka et al. (2011); Zaglool et al. (2016) in cattle. In contrast, according to the research in cattle (Ahmadi et al., 2008), and sheep (Mroczkowski et al., 2004; Dario et al., 2005), the studies reported that the $\beta$-LG gene had a significant effect on fat in AA genotype and whey protein in BB genotype.

This study showed that the association of $\beta$ LG genotypes (AA, AG, GG) with milk protein percentage did not differ significantly. The results of these studies are possible affected by several factors, some of them were population size, type of livestock, frequency of genotypes, and statistical analysis models. This different of result may be to breed difference leading to different structure of $\beta-\mathrm{LG}$ gene and the frequency of genotypes, number of population and difference in statistical analysis models used (Selvaggi et al., 2015).

Some of the previous studies indicate that the $\beta-\mathrm{LG}$ genotype (AA and $\mathrm{BB}$ ) is associated with milk proteinls, while in this study showed showed that $\beta$-LG genotype (AA, AG, GG) was not associated with milk protein. Not all of the results from different studies can be compared with each other for several reasons, including differences in livestock breeding types and genotype frequencies (Selvaggi et al., 2015). Furthermore Selvaggi et al. (2015) stated that the results of research on the association of the $\beta-L G$ gene with different milk production traits can be caused by a lack of relationship information in the livestock of sample population (differences in the background of the origin of the livestock population). In addition, it can also be caused by interactions between genetics and the environment. In a population, the diversity of phenotypes is caused by the diversity of genotypes and environmental effect and the possibility of genetic-environmental interaction (Kurnianto, 2009). Because geneticenvironmental interactions can inhibit the expression of the superiority of traits that should be shown by a particular genotype.

\section{CONCLUSION}

Two alleles (A and $G$ ) forming two homozygous genotypes (AA and $\mathrm{GG}$ ) and one heterozygous genotype AG were found. The AG genotype showed the highest frequency, then followed by AA genotype and GG genotype. The frequency of $\mathrm{A}$ allele was dominant compared to $\mathrm{G}$ allele. The $\beta-\mathrm{LG}$ was in high diversity showed by high heterozygosity value The $\beta$-LG genotyping association with milk protein and milk production in Saanen goats showed no significant differences.

\section{ACKNOWLEDGMENTS}

Authors are thankful to the Director of Baturraden Animal Breeding and Forage Center for providing facilities to study this topic.

\section{REFERENCES}

Ahmadi, M., Y. Mohammadi, D.H. Kuhi, R. Osfoori, and S. Qanbari. 2008. Association of milk protein genotypes with production traits and somatic cell count of Holstein cows. J. Biol. Sci. 8(7):1231-1235.

Batista, J., L.Z. Zuniga, A.R. Flores, R.N. Domingues, and R.R. Valverde. 2015. Polymorphism of three milk protein genes in Mexican Jersey cattle. EJB. 18:1-4.

Coral J. M., J.A. Padilla, and M. Izquierdo. 2010. Associations between milk protein genetic polymorphisms and milk production traits in Merino sheep breed. Livest. Sci. 129(1): 7379.

Culotta, C.P. and G.H. Schmidt. 1988. An economic evaluation of three times daily milking of dairy cows. J.Dairy.Sci. 71:19601966.

Dario, C., D. Carnicella, and G. Bufano. 2005. Effect of $\beta$-lactoglobulin genoypes on ovine milk composition in Altamurana breed. Archive Zootechnology. 54(1):105-108.

El-Hanafy, A.A.M., A. El-Saadani, M. Eissa, G.M. Maharem, and Z.A. Khalifa. 2010. Polymorphism of $\beta$-lactoglobulin gene in Barki and Damascus and their crossbred goats in relation to milk yield. Biotechnol. Anim. Husbandry. 26(1-2):1-12.

El Hanafy, A.A.M., M.I. Qureshi, J. Sabir, M. Mutawakil, M.M.M. Ahmed, H. El Ashmaoui, H.A.M.I. Ramadan, M. AbouAlsoud, and M.A. Sadek. 2015. Nucleotide 
sequencing and DNA polymorphism studies of beta-lactoglobulin gene in native Saudi goat breeds in relation to milk yield. Czech J. Anim. Sci. 60(3):132-138.

El-Rafey, G. A. and S. F. Darwish. 2008. A PCRRFLP assay to detect genetic variants of kappa-casein gene in cattle and buffalo. Arab J. Biotechnol. 11:11-28.

El-Shazly, S.A., M.E. Mahfouz, S.A. Otaibi, and M.M. Ahmed. 2012. Genetic polymorphism in beta-lactoglobulin gene of some sheep breeds in KSA and its influence on milk composition. Afr. J. Biotechnol. 11(19):4330-4337.

Ensminger, M. E. and D.T. Howard. 2006. Dairy Cattle Science. $4^{\text {th }}$ Ed. The Interstate Printers and Publisher, Inc. Danville.

Gharedaghi, L., H.M. Shahrbabak, and M. Sadeghi. 2016. Identification of novel SNP in caprine $\beta$-laktoglobulin gene. J. Genet. Genomics. 95(3):485-490.

Falconer, D. and T. Mackay. 1996. Introduction to Quantitative Genetics. Pearson Education Limited, Harlow, UK.

Hambling, S.G., A. McAlpine, L. Sawyer. 1992. b-lactoglobulin. In: Fox PF (ed) Advanced dairy chemistry-1. Proteins. Elsevier Applied Science, New York.

Hartl, D. L. and A. G. Clark. 1997. Principles of Population Genetics 3rd Ed. Sinauer Associates Inc, Sutherland.

Isik, R., G. Bihen, N. Kosum, C. Kandemir, and T. Taskin. 2017. Polimorphism in exon 7 of $\beta$ lactoglobulin ( $\beta$-LG) gene and its association with milk yield in saanen goats. JOTAF. 35-40.

Jain A., D.S. Gour, P.S. Bisen, P.P. Dubey, D.K. Sharma, R.P. Tiwari, N. Gupta, and D. Kumar. 2012. Allele mining in $\beta$ lactoglobulin gene of capra hircus. Afr. J. Biotechnol. 11(50):11057-11064.

Kahilo, K., S. El-Shazly, A. EL-Khadrawy, and I. Fattouh. 2014. Genetic polymorphism in $\beta$ lactoglobulin gene of some goat breeds in Egypt and its influence on milk yield. Life Sci.J. 11(10):232-238.

Kawecka, A. and A. Radko. 2011. Genetic polymorphism of $\beta$-lactoglobulin in sheep raised for milk production. J. App. Anim. Res. 39(1):68-71

Kishore, A., M. Mukesh, R.C. Sobti, K. Keviletsu, B.P. Mishra, and M. Sodhi. 2014. Single nucleotide polymorphism in exon 4 and promoter regions of $\beta$-lactoglobulin gene in native cattle (Bosindicus) breeds of India. J. Dairy Res. 2(3):135-131.

Kontopidis, G., C. Holt, and L. Sawyer. 2004. Invited review: $\beta$-Lactoglobulin: binding properties, structure, and function. J. Dairy Sci. 87(4):785-796.

Kumar, A., P.K Rout, and R. Roy. 2006. Polymorphism of $\beta$-lactoglobulin gene in Indian goats and its effect on milk yield. J. Appl. Genet. 47(1):49-53.

Kusza, S., N. Sziszkosz, K. Nagy, A. Masala, S. Kukovics, and J. Andras. 2015. Preliminary result of genetic polymorphism of $\beta$ lactoglobulin gene and the phylogenetic study of ten Balkan and Central European indigenous sheep breeds. Acta Biochim. Pol. 62(1):109-112.

Lekerpes, S.S., J.O. Junga, M.S. Badamanaa, and D.I. Rubenstein. 2014. Genetic polymorphism of beta-lactoglobulin in Kenyan small east African goat breed using PCR-RFLP and sequencing. Sci. J. Anim. Sci. 3(9):233-239.

Mele, M., G. Conte, A. Serra, A. Buccioni, and P. Secchiari. 2007. Relationship between betalactoglobulin polymorphism and milk fatty acid composition in milk of Massese dairy ewes. Small Rumin. Res. 73(1):37-44.

Mir S. N., O. Ullah, and R. Sheikh. 2014. Genetic polymorphism of milk protein variants and their association studies with milk yield in Sahiwal cattle. Afr.J Biotechnol. 13(4):555565.

Mroczkowski, S., K. Korman, G. Erhardt, D. Piwczynski, and B. Burys. 2004. Sheep milk protein polymorphism and its effects on milk performance of Polish Merino. Arch Tierz Dummerstorf. 47(1):114-121.

Nei, M. 1987. Molecular Evolutionary Genetics. Columbia University Press, New York.

Nei, M. and S. Kumar. 2000. Molecular evolution and phylogenetics. New York: Oxford University Press.

Ng-Kwai-Hang, K.F. $1998 . \quad$ Genetic polymorphism of milk proteins: relationships with production traits, milk composition and technological properties. Can. J. Anim. Sci. 78(4):131-147.

Patel, R.K., J.B. Chauhan, K.M. Singh, and K.J. Soni. 2007. Allelic frequency of kappacasein and beta-lactoglobulin in Indian Crossbred (Bos taurus $\mathrm{x}$ Bos indicus) dairy bulls. Turk. J. Vet. Anim. Sci. 31(6):399402. 
Pena, R.N., A. Sanchez, and J.M. Folch. 2000. Characterization of genetic polymorphism in the goat b-lactoglobulin gene. J. Dairy Res. 67:217-224.

Piątkowska, C. E., M. Szewczuk, A. Olszewska, and E. Chociłowicz. 2011. Association between beta-lactoglobulin (lgb) polymorphism and yield and composition of milk of Holstein Friesian cows imported from Sweden. Acta Sci. Pol. Technol. 10(1):9-18.

Sambrook J. and D.W. Russel. 2001. Molecular Cloning: A laboratory Manual. $3^{\text {rd }}$ ed. Cold Spring Harbor, NY, USA: Cold Spring Harbor Laboratory Press.

Selvaggi, M., V. Laudadio, C. Dario and V. Turafell. 2015. b-Lactoglobulin gene polymorphism in sheep and effect on milk production traits : A Review. Adv. Anim. Vet. Sci. 3(9):478-484.

Singh, U., R. Deb, S. Kumar, R. Singh, G. Sengar, and A. Sharma. 2014. Association of prolactin and beta-lactoglobulin genes with milk production traits and somatic cell count among Indian Fieshwal (HF X Sahiwal) cows. Biomarkers and Genomic Medicine. 7(1):38-42.

Sugiharto, S., B.B. Jensen , K.H. Jensen, and C. Lauridsen. 2015. Prevention of enterotoxigenic escheria coli infectious in pigs by diary based nutrition. $\mathrm{CAB}$ reviews.
$10(52): 1-15$

Vacca, G.M., M.L. Dettori, G. Piras, F. Manca, P. Paschino, and M. Pazzola. 2014. Goat casein genotypes are associated with milk production traits in the Sarda breed. Anim. Genet. 45(5):723-731.

Warwick, E. J., J. M. Astuti and Hardjosubroto. 1990. Pemuliaan Ternak. Gadjah Mada University Press, Yogyakarta.

Yang, F., L. Li, H. Liu, Y. Cai, and G. Wang. 2012. Polymorphism in the exon 4 of $\beta$ lactoglobulin variant $\mathrm{B}$ precursor gene and its association with milk traits and protein structure in Chinese Hostein. Mol. Biol. Rep. 39(4):3957-3964.

Yuksel, M. and B. Akyus. 2014. Detection of beta-lactoglobulin gene polymorphism with PCR-RFLP method in hair goat breed raising at Kayseri and Province. J. Health Sci. 23(2):62-66.

Zaglool, A.W., A. Awad, I.E. El Araby, and K.M. El-Bayomi. 2016. Association of $\beta$ Lactoglobulin gene polymorphism with milk yield, fat and protein in HolsteinFriesian Cattle. World J. Vet. 6(3):117-122.

Zurriyati, Y., R.R. Noor, and R. R. A. Maheswari. 2011. Analisis molekuler genotipe Kappa Kasein (K-Kasein) dan komposisi susu kambing Peranakan Etawah, Saanen dan persilangannya. JITV. 16(1):61-70. 